\title{
ANALISIS KADAR SAKARIN PADA HALUS MANIS YANG DIPERJUALBELIKAN DI KOTA MAKASSAR
}

\author{
Waode Rustiah ${ }^{1)}$, Nurul Ni'ma Azis ${ }^{1)}$ Aulia Putri Cahyani Kaempe ${ }^{1)}$. \\ ${ }^{1)}$ Teknologi Laboratorium Medis, Politeknik Kesehatan Muhammadiyah Makassar \\ Alamat Korespondensi: waoderustiah79@gmail.com
}

\begin{abstract}
Artikel info:
Received: November 2021

Revised: Desember 2021

Accepted: Desember 2021

Publish: Desember 2021
\end{abstract}

\begin{abstract}
Abstrak
Halus manis merupakan jajanan yang terbuat dari gula pasir yang diberi pewarna makanan dan dibuat menggunakan alat khusus yang berputar dan menghasilkan serat-serat gula yang halus. Dalam produksi halus manis terkadang ada pedagang menambahkan Bahan Tambahan Makanan (BTM) berupa sakarin. Sakarin adalah zat pemanis buatan dengan rumus kimia $\left(\mathrm{C}_{7} \mathrm{H}_{5} \mathrm{NO}_{3} \mathrm{~S}\right)$, berbentuk bubuk kristal putih, mudah larut dalam air, tidak berbau dan sangat manis. Efek samping penggunaan sakarin dapat menyebabkan gangguan tenggorokan berupa batuk dan radang tenggorokan serta dapat menimbulkan kerusakan membran sel serta timbulnya kanker kandung kemih karena bersifat karsiogenik jika dikonsumsi dalam kurun waktu yang lama. Penelitian ini bertujuan untuk mengetahui kadar sakarin dengan teknik pengambilan sampel random sampling dengan jumlah 10 sampel. Berdasarkan hasil penelitian uji kualitatif menggunakan uji kolorimetri diperoleh 7 sampel negatif (70\%) dan 3 sampel positif (30\%). Selanjutnya uji kuantitatif menggunakan uji alkalimetri diperoleh sampel 1 dengan kadar sakarin 0,0096 mg/kg, sampel 2 dengan kadar sakarin 0,0085 mg/kg dan sampel 5 dengan kadar sakarin 0,0096 mg/kg. Menurut Permenkes RI No. 722/Menkes/Per/IX/1988 mengenai bahan tambahan makanan, batas maksimum sakarin yaitu $50-300 \mathrm{mg} / \mathrm{kg}$ bahan. Sehingga dapat disimpulkan bahwa halus manis yang diperjualbelikan di kota Makassar masih layak dikonsumsi karena masih masuk ambang batas yang ditetapkan.
\end{abstract}

Kata Kunci: Halus manis, Sakarin, Kolorimetri, Alkalimetri

\begin{abstract}
Smooth sweet is a snack made from granulated sugar that is given food coloring and made using a special tool that rotates and produces fine sugar fibers. In the production of refined sweet, sometimes there are traders who add food additives (BTM) in the form of saccharin. Saccharin is an artificial sweetener with the chemical formula $\left(\mathrm{C}_{7} \mathrm{H}_{5} \mathrm{NO}_{3} \mathrm{~S}\right)$, in the form of a white crystalline powder, easily soluble in water, odorless and very sweet. Side effects of using saccharin can cause throat disorders in the form of coughing and sore throat and can cause cell membrane damage and bladder cancer because it is carcinogenic if consumed for a long time. This study aims to determine the levels of saccharin by sampling random sampling technique with a total of 10 samples. Based on the results of the qualitative test using the colorimetric test, 7 negative samples (70\%) and 3 positive samples (30\%). Furthermore, the quantitative test using the alkalimetry test obtained sample 1 with a saccharin level of $0.0096 \mathrm{mg} / \mathrm{kg}$, sample 2 with a saccharin level of $0.0085 \mathrm{mg} / \mathrm{kg}$ and sample 5 with a saccharin level of $0.0096 \mathrm{mg} / \mathrm{kg}$. According to the Regulation of the Minister of Health of the Republic of Indonesia No. 722/Menkes/Per/IX/1988
\end{abstract}


regarding food additives, the maximum limit for saccharin is 50-300 $\mathrm{mg} / \mathrm{kg}$ of ingredients. So it can be concluded that the sweet smooth that is traded in Makassar city is still suitable for consumption because it is still within the stipulated threshold.

Keywords: Smooth sweetness, Saccharin, Colorimetry, Alkalimetry

\section{PENDAHULUAN}

Jajanan adalah makanan atau minuman yang dibeli dari penjual makanan dan dapat langsung dikonsumsi baik yang diproduksi langsung oleh penjual atau hasil produksi orang lain tanpa diolah kembali (BPOM, 2014). Pangan merupakan salah satu kebutuhan pokok manusia juga salah satu bagian yang penting untuk kesehatan manusia (Rustiah and Umriani, 2018; Yunantariningsih et al., 2019). Salah satu jajanan yang banyak diminati yaitu halus manis.

Halus manis adalah salah satu makanan tradisional khas Indonesia yang cukup populer pada masanya. Halus manis atau permen kapas merupakan makanan yang berbasis gula yang banyak diminati mulai dari kalangan anak-anak hingga orang dewasa karena mempunyai cita rasa yang manis (Kusumaningrum and Fitriah, 2020).

Halus manis merupakan jajanan yang terbuat dari gula pasir yang diberi pewarna makanan dan dibuat menggunakan alat khusus yang berputar dan menghasilkan serat-serat gula yang halus (Wandira, Ilyas and Nardin, 2018; Yunantariningsih et al., 2019). Akan tetapi, dikarenakan kondisi harga gula yang tidak stabil dan atau terus meningkat setiap tahunnya membuat para produsen memodifikasi komposisi dari suatu bahan makanan dengan menambahkan bahan tambahan makanan seperti pemanis buatan. Salah satu bahan tambahan makanan yang sering ditemukan yaitu sakarin (Akbar, 2019; Olivea Herman, Ari Yusasrini and Kencana Putra, 2021).

Sakarin adalah zat pemanis buatan dengan rumus kimia $\left(\mathrm{C}_{7} \mathrm{H}_{5} \mathrm{NO}_{3} \mathrm{~S}\right)$, berbentuk bubuk kristal putih, mudah larut dalam air, tidak berbau dan sangat manis. Pemanis buatan ini mempunyai tingkat kemanisan 550 kali dari gula biasa (Wariyah, Hartati and Dewi, 2013; Nasir and Idris, 2018).

Menurut Peraturan Menteri Kesehatan Republik Indonesia No. 722/Menkes/Per/IX/1998 mengenai bahan tambahan makanan, batas maksimum sakarin yaitu $50-300 \mathrm{mg} / \mathrm{kg}$ bahan dan dibatasi tingkat konsumsi untuk sakarin sebesar $0-5 \mathrm{mg} / \mathrm{kg}$ berat badan/hari. Jadi bila berat badan kita $50 \mathrm{~kg}$, maka jumlah maksimum sakarin yang boleh dikonsumsi per hari adalah 50x5 mg atau $250 \mathrm{mg}$ (Noriko et al., 2011). Meskipun penambahan sakarin telah diizinkan oleh pemerintah, akan tetapi harus sesuai ambang batas penggunaannya karena jika penggunaan melebihi ambang batas dengan jangka waktu yang lama akan menimbulkan efek samping bagi kesehatan (Sitorus, 2016; Marliza, Mayefis and Islamiati, 2020).

Efek samping penggunaan sakarin bagi kesehatan yaitu jangka waktu pendek dapat menyebabkan sakit perut, diare, sakit kepala, mual dan muntah-muntah (Tahir and Vitrianty, 2013). Sedangkan dalam waktu lama dapat menimbulkan kerusakan membran sel ditandai dengan peningkatan Serum Glutamic Pyruvic Transaminase (SGPT) dan atau Serum Glutamic Oxaloacetic Transaminase (SGOT) di darah (Wariyah, Hartati and Dewi, 2013; Alifudin and Miftakhurrohmat, 2015).

Hasil penelusuran penelitian sebelumnya (Yunantariningsih et al., 2019) dengan judul "Analisis Pemanis Buatan Sakarin pada Pangan Jajanan Anak Sekolah Dasar di Kecamatan Denpasar Selatan" memperoleh hasil yang menunjukkan bahwa dari 110 sampel, didapatkan sebanyak 39 sampel (35\%) yang mengandung sakarin. 
Berdasarkan uraian di atas maka
peneliti berkeinginan melakukan penelitian dengan judul "Analisis Kadar pada Halus Manis yang Diperjualbelikan di Kota Makassar".

\section{METODE PENELITIAN}

Alat dan Bahan

Alat yang digunakan dalam penelitian ini adalah labu ukur, gelas ukur, corong pisah, erlenmeyer, buret, gelas beaker, klem dan statif, hotplate, timbangan analitik, tabung reaksi, rak tabung, api bunsen, penjepit tabung, pipet tetes, batang pengaduk, cawan porselin.

Bahan yang digunakan adalah halus manis, $\mathrm{HCl} 5 \%, \mathrm{NaOH} 10 \%, \mathrm{NaOH} 0,1$ $\mathrm{N}$, indikator $\mathrm{BTB}$, asam oksalat, $\mathrm{HCl}$, Eter, $\mathrm{H}_{2} \mathrm{SO}_{4}$ pekat, resorsinol, kloroform, aquadest, indikator PP, sakarin.

\section{Prosedur Kerja}

Pembuatan kontrol positif

Ditimbang $100 \mathrm{mg}$ sakarin dan dilarutkan terlebih dahulu dalam $100 \mathrm{~mL}$ aquadest lalu diasamkan dengan $\mathrm{HCl}$ sebanyak $1 \mathrm{~mL}$, kemudian diekstrasi 1 kali dengan $25 \mathrm{~mL}$ eter. Setelah terpisah, lapisan eter dipanaskan di atas hotplate selama 1-3 menit. Setelah dipanaskan, residu yang diperoleh ditambahkan 18 dengan 10 tetes $\mathrm{H} 2 \mathrm{SO} 4$ pekat lalu dipindahkan ke dalam tabung reaksi, ditambah dengan $40 \mathrm{mg}$ resorsinol dan dipanaskan secara perlahan-lahan dengan api bunsen. Setelah didinginkan, ditambahkan larutan $\mathrm{NaOH} \quad 10 \%$ sebanyak $6 \mathrm{~mL}$.

\section{Pembuatan kontrol negatif}

$100 \mathrm{~mL}$ aquadest diasamkan dengan $\mathrm{HCl}$ sebanyak $1 \mathrm{~mL}$, kemudian diekstrasi 1 kali dengan $25 \mathrm{~mL}$ eter. Setelah terpisah, lapisan eter dipanaskan di atas hotplate selama 1-3 menit. Setelah dipanaskan, residu yang diperoleh ditambahkan dengan 10 tetes $\mathrm{H}_{2} \mathrm{SO}_{4}$ pekat lalu dipindahkan ke dalam tabung reaksi, ditambah dengan $40 \mathrm{mg}$ resorsinol dan dipanaskan secara perlahan-lahan dengan api bunsen. Setelah didinginkan, ditambahkan larutan $\mathrm{NaOH} \quad 10 \%$ sebanyak $6 \mathrm{~mL}$.

\section{Analisis kualitatif sakarin (Metode Kolorimetri)}

Ditimbang $100 \mathrm{mg}$ sampel (halus manis) dan dilarutkan terlebih dahulu dalam $100 \mathrm{~mL}$ aquadest lalu diasamkan dengan $\mathrm{HCl}$ sebanyak $1 \mathrm{~mL}$, kemudian diekstrasi 1 kali dengan $25 \mathrm{~mL}$ eter. Setelah terpisah, lapisan eter dipanaskan di atas hotplate selama 1- 3 menit. Setelah dipanaskan, residu yang diperoleh ditambahkan dengan 10 tetes $\mathrm{H}_{2} \mathrm{SO}_{4}$ pekat lalu dipindahkan ke dalam tabung reaksi, ditambah dengan $40 \mathrm{mg}$ resorsinol dan dipanaskan secara perlahan-lahan dengan api bunsen. Setelah didinginkan, ditambahkan larutan $\mathrm{NaOH} \quad 10 \%$ sebanyak 6 mL (Sumantri, 2013).

Interpretasi hasil: jika terbentuk flouresensi warna hijau menunjukkan adanya sakarin (Positif (+) sakarin)

Standarisasi larutan Natrium hidroksida (NaOH) 0,1N dengan Asam Oksalat (C2H2O4)

Ditimbang $100 \mathrm{mg}$ asam oksalat. Kemudian dilarutkan dengan $50 \mathrm{~mL}$ aquadest dalam labu ukur. Kemudian dipipet $25 \mathrm{~mL}$ larutan tersebut ke dalam Erlenmeyer, ditambahkan 3 tetes indikator fenolftalein (PP) lalu dititrasi dengan larutan $\mathrm{NaOH}$ sampai timbul warna merah muda. Perlakuan diulangi 2 kali. Hitung normalitas.

\section{Analisis Kuantitatif Sakarin (Metode Alkalimetri)}

Ditimbang $50 \mathrm{mg}$ sampel lalu ditambahkan $2 \mathrm{~mL} \mathrm{HCl} \mathrm{5 \% .} \mathrm{Sampel}$ diekstraksi sebanyak 3 kali dengan kloroform masingmasing $30 \mathrm{~mL}, 20 \mathrm{~mL}$, dan $20 \mathrm{~mL}$. Hasil ekstraksi diuapkan lalu ditambahkan $50 \mathrm{~mL}$ aquadest. Selanjutnya sampel ditambahkan dengan indikator BTB (Bromthimol Blue) sebanyak 3 tetes kemudian dititrasi dengan $\mathrm{NaOH} 0,1 \mathrm{~N}$. Titik akhir titrasi ditandai dengan warna biru sebagai pertanda bahwa zat-zat tersebut telah habis bereaksi (Nur Qadri Rasyid, 2019). 


\section{HASIL DAN PEMBAHASAN}

Penelitian ini telah dilaksanakan di Laboratorium Kimia dan Toksikologi Klinik Poltekkes Muhammadiyah Makassar. Penelitian ini telah dilaksanakan pada 17-20 April 2021. Teknik pengambilan sampel pada penelitian ini adalah secara random sampling, yaitu cara pengambilan sampel secara acak.

Berdasarkan hasil penelitian yang telah dilakukan di Laboratorium Toksikologi, Politikneik Kesehatan Muhammadiyah Makassar pada tanggal 17-20 April 2021, pada 10 sampel Halus Manis yang beredar di kota Makassar, diperoleh hasil sebagai berikut:

Tabel 1. Hasil Uji Kualitatif Menggunakan Metode Kolorimetri

\begin{tabular}{|c|c|c|c|}
\hline Kode sampel & Warna yang didapat & Hasil & Keterangan \\
\hline 1 & Flouresensi Hijau & Positif (+) & $\begin{array}{l}\text { Terbentuk Flouresensi } \\
\text { Hijau }\end{array}$ \\
\hline 2 & Flouresensi Hijau & Positif (+) & $\begin{array}{l}\text { Terbentuk Flouresensi } \\
\text { Hijau }\end{array}$ \\
\hline 3 & Kuning Keruh & Negatif (-) & $\begin{array}{l}\text { Tidak Terbentuk } \\
\text { Flouresensi Hijau }\end{array}$ \\
\hline 4 & Kuning Keruh & Negatif (-) & $\begin{array}{l}\text { Tidak Terbentuk } \\
\text { Flouresensi Hijau }\end{array}$ \\
\hline 5 & Flouresensi Hijau & Positif (+) & $\begin{array}{l}\text { Terbentuk Flouresensi } \\
\text { Hijau }\end{array}$ \\
\hline 6 & Flouresensi Kuning & Negatif (-) & $\begin{array}{l}\text { Tidak Terbentuk } \\
\text { Flouresensi Hijau }\end{array}$ \\
\hline 7 & Cokelat Muda & Negatif (-) & $\begin{array}{l}\text { Tidak Terbentuk } \\
\text { Flouresensi Hijau }\end{array}$ \\
\hline 8 & Putih Keruh & Negatif (-) & $\begin{array}{l}\text { Tidak Terbentuk } \\
\text { Flouresensi Hijau }\end{array}$ \\
\hline 9 & Cokelat Muda & Negatif (-) & $\begin{array}{l}\text { Tidak Terbentuk } \\
\text { Flouresensi Hijau }\end{array}$ \\
\hline 10 & Merah & Negatif (-) & $\begin{array}{l}\text { Tidak Terbentuk } \\
\text { Flouresensi Hijau }\end{array}$ \\
\hline $\begin{array}{l}\text { Kontrol Positif } \\
\text { Kontrol Negatif }\end{array}$ & \multicolumn{3}{|c|}{$\begin{array}{c}\text { Flouresensi Hijau } \\
\text { Cokelat }\end{array}$} \\
\hline
\end{tabular}

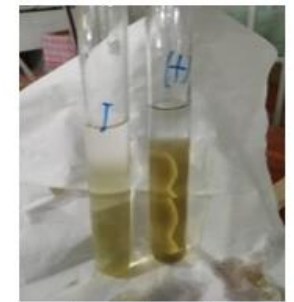

Sampel no. 1

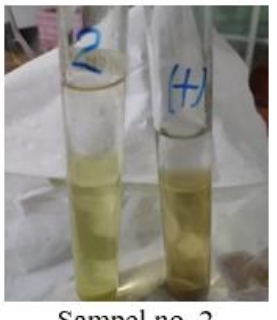

Sampel no. 2

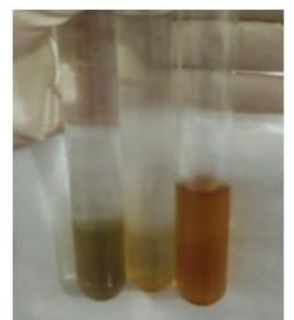

Sampel no. 3

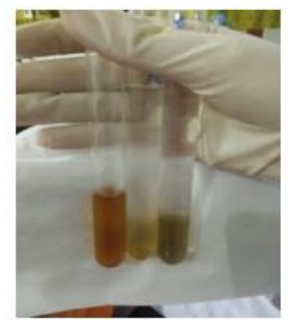

Sampel no. 4

Gambar 1. Hasil Uji Kualitatif Menggunakan Metode Kolorimetri Sampel 1-4 


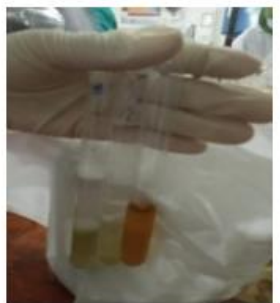

Sampel no. 5

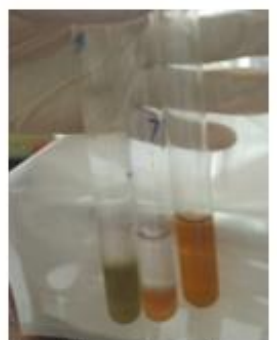

Sampel no. 7

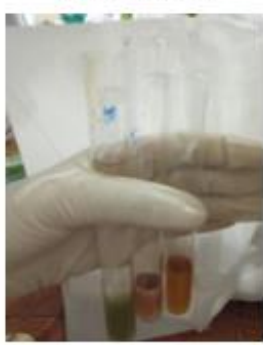

Sampel no. 9

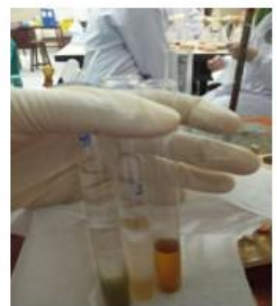

Sampel no. 6

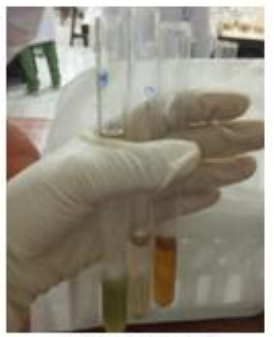

Sampel no. 8

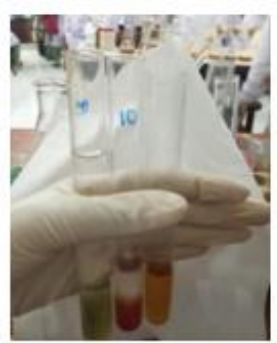

Sampel no. 10
Berdasarkan tabel 1 dan gambar 1 , hasil uji kualitatif sakarin pada 10 sampel halus manis yang diperjualbelikan di kota Makassar didapatkan hasil 3 sampel positif mengandung sakarin, kemudian dilanjutkan uji kuantitatif untuk mengetahui kadar sakarin yang terdapat dalam sampel halus manis menggunakan uji alkalimetri dengan hasil sebagai berikut:

Tabel 2. Hasil Uji Kuantitatif Menggunakan Metode Alkalimetri

\begin{tabular}{ccc}
\hline Sampel & Warna & $\begin{array}{c}\text { Hasil } \\
(\mathbf{m g} / \mathbf{k g})\end{array}$ \\
\hline Kontrol Positif & Biru & 0,0095 \\
1 & Biru & 0,0096 \\
2 & Biru & 0,0085 \\
5 & Biru & 0,0096 \\
\hline
\end{tabular}

Sumber: Data Primer, 2021

Gambar 2. Hasil Uji Kualitatif Menggunakan Metode Kolorimetri Sampel 5-10

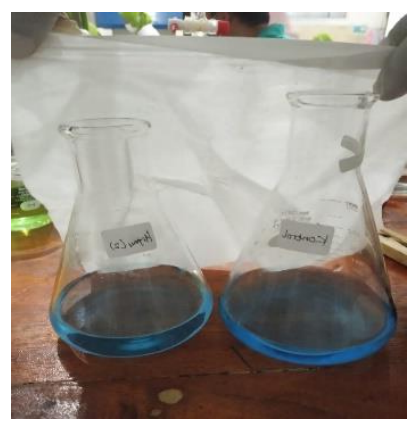

Sampel no. 1

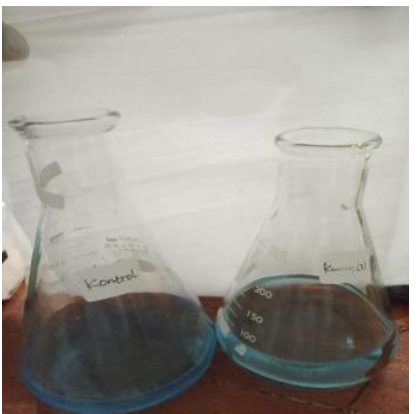

Sampel no. 2

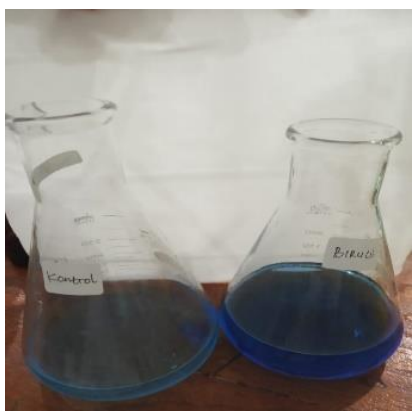

Sampel no. 5

Gambar 3. Hasil yang diperoleh setelah penambahan Indikator BTB dan dititrasi dengan $\mathrm{NaOH} 0,1 \mathrm{~N}$ 
Berdasarkan tabel 2 uji kuantitatif dengan metode alkalimetri diperoleh hasil sampel 1 dengan kadar sakarin 0,0096 $\mathrm{mg} / \mathrm{kg}$, sampel 2 dengan kadar sakarin $0,0085 \mathrm{mg} / \mathrm{kg}$, dan sampel 3 dengan kadar sakarin $0,0096 \mathrm{mg} / \mathrm{kg}$ yang tidak melebihi ambang batas sesuai dengan Permenkes RI No. 722/Menkes/Per/IX/1998.

Sebelum melakukan analisis kadar pada penelitian ini terlebih dahulu dilakukan analisis kualitatif pada 10 sampel halus manis yang diperjualbelikan di kota Makassar yang bertujuan untuk mengetahui kandungan sakarin pada sampel halus manis tersebut.

Uji kualitatif sakarin ini dilakukan menggunakan metode kolorimetri. Pada uji ini prinsipnya adalah sakarin akan memberikan warna hijau fluoresensi jika direaksikan dengan resorsinol dan $\mathrm{NaOH}$. Tahap pertama yang dilakukan pada sampel adalah penambahan larutan asam klorida (HCl) pada $100 \mathrm{~mL}$ sampel. Penambahan $\mathrm{HCl}$ berfungsi untuk mengasamkan larutan, larutan dibuat dalam keadaan asam agar reaksi yang akan terjadi dapat lebih mudah bereaksi. Kemudian diekstrasi dengan larutan eter $\left(\mathrm{C}_{2} \mathrm{H}_{5}\right)_{2} \mathrm{O}$ menggunakan corong pisah, ekstraksi dilakukan bertujuan untuk menarik komponen kimia yang terdapat dalam sampel. Setelah larutan dikocok didapatkan lapisan eter setelah itu hasil dari ekstrasi yaitu lapisan eter diuapkan di atas hotplate dan diperoleh residu, kemudian didinginkan. Setelah didinginkan dan ditambahkan asam sulfat $\left(\mathrm{H}_{2} \mathrm{SO}_{4}\right)$ pekat yang berfungsi untuk memecahkan garam pada sakarin dan ditambahkan dengan resorsinol $\left(\mathrm{C}_{6} \mathrm{H}_{6} \mathrm{O}_{2}\right)$ yang berfungsi sebagai agen pemberi warna hijau flouresensi saat bereaksi dengan sakarin. Kemudian dipanaskan kembali dengan menggunakan api bunsen yang bertujuan agar asam sulfat akan bereaksi dengan resorsinol dan terbentuk warna cokelat, setelah itu larutan di dinginkan dan ditambahkan $\mathrm{NaOH} 10 \%$ untuk memperjelas perubahan warna menjadi flouresensi hijau yang menandakan sampel positif adanya pemanis sakarin dalam sampel.

Pada uji kuantitatif sakarin ini dilakukan menggunakan metode alkalimetri. Dimana pada uji ini prinsipnya adalah sakarin bersifat asam dan dapat dititrasi langsung dengan natrium hidroksida $0,1 \mathrm{~N}$ menggunakan indikator PP. Tahap pertama sampel ditambahkan $\mathrm{HCl} 5 \%$ yangbertujuan untuk mengasamkan larutan lalu diekstrasi dengan kloroform agar sakarin yang terdapat pada sampel dapat terikat seluruhnya. Selain itu menggunakan juga $\mathrm{NaOH} 0,1 \mathrm{~N}$ untuk menentukan jumlah kadar sakarin dalam suatu sampel pada saat titrasi dan indikator BTB (Bromthimol Blue) sebagai petunjuk dari larutan yang semula berwarna kuning keruh menjadi warna biru sebagai tanda bahwa zat-zat tersebut telah habis bereaksi setelah diekstrasi dengan $\mathrm{NaOH}$ $0,1 \mathrm{~N}$.

Hasil yang didapatkan pada masing-masing sampel yaitu sampel 1 sebesar $0,0096 \mathrm{mg} / \mathrm{kg}$, sampel 2 sebesar $0,0085 \mathrm{mg} / \mathrm{kg}$, dan sampel 5 sebesar $0,0096 \mathrm{mg} / \mathrm{kg}$. Berdasarkan Permenkes Nomor 722/Menkes/Per/IX/1998 tentang Bahan Tambahan Makanan, batas maksimum sakarin yaitu $50-300 \mathrm{mg} / \mathrm{kg}$. Menurut Food and Drug Administration (FDA) asupan harian (Acceptable Daily Intake) sakarin tidak boleh melebihi 5 $\mathrm{mg} / \mathrm{kg}$ berat badan. Penelitian ini mengukur kadar sakarin pada seluruh sampel dengan metode titrasi alkalimetri, menunjukkan bahwa terdapat sakarin pada sampel dengan kadar yang tidak melebihi ambang batas.

Sakarin dapat terakumulasi di dalam hati karena hati merupakan tempat metabolisme dari seluruh bahan makanan, sebagai perantara sistem pencernaan dengan darah, dan tempat detoksifikasi dalam tubuh. Sakarin pada plasma (serum) akan menyebabkan peningkatan radikal bebas (Noriko et al., 2011; Olivea 
Herman, Ari Yusasrini and Kencana Putra, 2021).

Mengonsumsi makanan yang mengandung sakarin berulang dalam jangka pendek dapat menyebabkan gangguan tenggorokan berupa batuk dan radang tenggorokan, sakit perut, diare, sakit kepala, mual dan muntah-muntah. Sedangkan dalam waktu lama dapat menimbulkan kerusakan membran sel ditandai dengan peningkatan Serum Glutamic Pyruvic Transaminase (SGPT) dan atau Serum Glutamic Oxaloacetic Sransaminase (SGOT) (Histopatologi et al., 2012; Wariyah, Hartati and Dewi, 2013; Rustiah et al., 2020).

\section{KESIMPULAN DAN SARAN}

Berdasarkan penelitian yang telah dilakukan uji kuantitatif dengan metode alkalimetri diperoleh hasil sampel 1 dengan kadar sakarin $0,0096 \mathrm{mg} / \mathrm{kg}$, sampel 2 dengan kadar sakarin 0,0085 $\mathrm{mg} / \mathrm{kg}$, dan sampel 3 dengan kadar sakarin $0,0096 \mathrm{mg} / \mathrm{kg}$ yang tidak melebihi ambang batas sesuai dengan Permenkes RI No. 722/Menkes/Per/IX/1998 mengenai bahan tambahan makanan, batas maksimum sakarin yaitu 50-300 $\mathrm{mg} / \mathrm{kg}$ bahan dan dibatasi tingkat konsumsi untuk sakarin sebesar 0-5 $\mathrm{mg} / \mathrm{kg}$ berat badan/hari.yang terkait dengan apa yang ada dalam penelitian tersebut.

\section{UCAPAN TERIMAKASIH}

Ucapan terima kasih yang luar biasa untuk semua pihak yang sudah banyak membantu penelitian ini hingga dapat terlaksana dengan baik.

\section{DAFTAR PUSTAKA}

Akbar, F. K. R. (2019) 'Analisis Risiko K3 Pemberantasan Hama Pekerjaan Pertanian Jeruk', Journal of Public Health Research and Community Health Development, 3(1), p. 01. doi:

10.20473/jphrecode.v3i1.13067.

Alifudin, U. and Miftakhurrohmat, A.

(2015) 'Uji Perbandingan Pewarna

Sintesis Dengan Pewarna Alami Terhadap Kualitas Gula Kapas',
Jurnal Nabatia, 12(1), pp. 22-23.

BPOM (2014) 'Persyaratan Mutu Obat Tradisional', Badan Pengawas Obat dan Makanan, pp. 1-25.

Histopatologi, S. et al. (2012) 'STUDI HISTOPATOLOGI HATI MENCIT (Mus musculus L.) YANG DIINDUKSI PEMANIS BUATAN', Jurnal MIPA Unnes, 35(2), p. 114470.

Kusumaningrum, N. and Fitriah, F. (2020) 'Perancangan Pembuatan Permen Kapas Otomatis Berbasis Arduino Uno', TESLA: Jurnal Teknik Elektro, 22(1), p. 12. doi: 10.24912/tesla.v22i1.7810.

Marliza, H., Mayefis, D. and Islamiati, R. (2020) 'Analisis Kualitatif Sakarin dan Silamat pada Es Doger di Kota Batam', Jurnal Farmasi Dan Ilmu Kefarmasian Indonesia, 6(2), p. 81. doi: 10.20473/jfiki.v6i22019.81-84.

Nasir, M. and Idris, F. (2018) 'Identifikasi Sakarin pada Kue Buroncong yang Dijual di Kecamatan Panakkukang Kota Makassar', Jurnal Media Analis Kesehatan, 9(2), pp. 136140. doi: 10.32382/mak.v9i2.685.

Noriko, N. et al. (2011) 'Studi Kasus Terhadap Zat Pewarna, Pemanis Buatan dan Formalin pada Jajanan Anak di SDN Telaga Murni 03 dan Tambun 04 Kabupaten Bekasi', JURNAL Al-AZHAR INDONESIA SERI SAINS DAN TEKNOLOGI,
$1(2)$ $\mathrm{p}$. 47.
doi: 10.36722/sst.v1i2.26.

Olivea Herman, N., Ari Yusasrini, N. L. and Kencana Putra, I. N. (2021) 'Identifikasi Sakarin, Siklamat, dan Natrium Benzoat Serta Karakteristik Susu Kedelai yang Dijual di Pasar Tradisional Wilayah Jimbaran, Bali Selama Penyimpanan', Jurnal Ilmu dan Teknologi Pangan (ITEPA), 10(1), p. $141 . \quad$ doi: 10.24843/itepa.2021.v10.i01.p13.

PERMENKES_NO_722_Menkes_PER_I X_1998. 
Rasyid, N. Q, Muawanah. 2019. Penuntun Praktikum Toksikologi I. Makassar: Akademi Analis Kesehatan Muhammadiyah Makassar

Rustiah, W. et al. (2020) 'Recent analysis of carbon, nitrogen, and lignin phenol compositions in the suspended particulate matters at spermonde archipelago, South Sulawesi, Indonesia', Environment and Natural Resources Journal, 18(2), pp. 124-133. doi: 10.32526/ennrj.18.2.2020.12.

Rustiah, W. and Umriani, N. (2018) 'Uji Aktivitas Antioksidan Pada Ekstrak Buah Kawista (Limonia Acidissima) Menggunakan Spektrofotometer UV-Vis', Indo. J. Chem. Res., 6(1), pp. 22-25. doi: 10.30598//ijcr.2018.6-wao.

Sitorus, E. N. (2016) 'Hubungan Karakteristik dan Perilaku Pedagang dengan Keberadaan Pemanis Sakarin dan Siklamat dalam Minuman Sirup pada Sekolah Dasar (SD) di Kecamatan Medan Johor Tahun 2014', Jurnal Farmanesia, 1(1), pp. 24-34.

Sumantri, Abdul Rohman, 2013. Analisis
Makanan. Yogyakarta: Gadjah Mada University Press.

Tahir, I. A. C. and Vitrianty, V. (2013) 'Analisis Kandungan Pemanis Buatan Pada Sari Buah Markisa Produksi Makassar', Jurnal Ilmiah As-Syifaa, 5(2), pp. 185-191. doi: 10.33096/jifa.v5i2.60.

Wandira, Y., Ilyas, S. R. and Nardin, N. (2018) 'Analisis Kadar Sakarin pada Beberapa Minuman Kemasan Bermerek yang Diperjualbelikan di Mall Uit Jalan Abdul Kadir Kota Makassar', Jurnal Media Laboran, 8(2), pp. 13-16.

Wariyah, C., Hartati, S. and Dewi, C. (2013) 'Penggunaan Pengawet dan Pemanis Buatan pada Pangan Jajanan Anak Sekolah (PJAS) di Wilayah Kabupaten Kulon ProgoDIY', Agritech, 33(02), pp. 146153. doi: 10.22146/agritech.9807.

Yunantariningsih, I. D. A. K. et al. (2019) 'Analisis Pemanis Buatan Sakarin Pada Pangan Jajanan Anak Sekolah Dasar Di Kecamatan Denpasar Selatan', Universitas Dhyana Putra SINTESA Prosiding 2019, pp. 409414. 